\title{
Partial purification and kinetic characterization of mushroom stem polyphenoloxidase and determination of its storage stability in different lyophilized forms
}

\author{
Şebnem Şimşek ${ }^{b}$, Ahmet Yemenicioğlu ${ }^{a, *}$ \\ ${ }^{a}$ Department of Food Engineering, Faculty of Engineering, Izmir Institute of Technology 35430, Gülbahçe Köyü, Urla, Izzmir, Turkey \\ ${ }^{\mathrm{b}}$ Department of Food Engineering, Faculty of Engineering, Ege University, 35100 Bornova, Izmir, Turkey
}

Received 9 February 2007; accepted 2 March 2007

\begin{abstract}
Monophenolase $(1011 \pm 626 \mathrm{U} / \mathrm{g}$ AP) and diphenolase activities (5163 $\pm 3059 \mathrm{U} / \mathrm{g}$ AP) of PPO in acetone powders (APs) of different mushroom stems varied considerably. However, the limited variation of average dipenolase (L-DOPA) to monophenolase (L-tyrosine) activity ratio $(5.4 \pm 0.7)$ in crude extracts showed the homogeneity of PPO from different mushroom stems. The change in extraction material or partial purification method (ammonium sulfate or acetone precipitation) did not affect the temperature stability, temperature and $\mathrm{pH}$ dependency and $K_{\mathrm{m}}$ of monophenolase activity considerably. However, some changes were observed in $\mathrm{pH}$ stability and substrate specificity of PPO in different parties of mushroom stems. The most important aspects of mushroom stem PPO are its lower diphenolase to monophenolase activity ratio than mushroom cap PPO, low temperature dependency of activity between 25 and $40{ }^{\circ} \mathrm{C}\left(E_{\mathrm{a}}=30 \mathrm{~kJ} / \mathrm{mol}\right)$, broad optimum pH between 6 and 8 , but lack of activity $\mathrm{pH} \leq 5$, and ability to use phloridzin as substrate. The mushroom stem PPOs partially purified and lyophilized by using sucrose, dextran or alginate showed moderate to high stability at $-18{ }^{\circ} \mathrm{C}$ for $6-6.5$ months. Thus, the mushroom stems obtained as a waste material during mushroom processing may be used as a more homogenous source than whole mushrooms to obtain PPO used for different industrial, clinical or research purposes.
\end{abstract}

(C) 2007 Elsevier Ltd. All rights reserved.

Keywords: Mushrooms; Stems; Polyphenoloxidase; Purification; Characterization; Storage stability

\section{Introduction}

Polyphenoloxidase (PPO) enzymes, members of oxidoreductases, are metalloenzymes found in many plants, fungi, animals and bacteria [1]. Different types of PPOs include tyrosinase, catechol oxidase and laccase. From these enzymes tyrosinase catalyzes hydroxylation of monophenols to $o$-diphenols (monophenolase or cresolase activity) and oxidation of $o$-diphenols to $o$-quinones (diphenolase or catecholase activity). Catechol oxidase catalyzes oxidation of $o$-diphenols to $o$-quinones, whereas laccase catalyzes oxidation of both $o$-diphenols and $p$-diphenols to corresponding quinones [2]. The quinons formed undergo non-enzymatic polymerization reactions resulting in the formation of dark colored melanins

\footnotetext{
* Corresponding author. Tel.: +90 232 7506292; fax: +90 2327506196. E-mail address: ahmetyemenicioglu@iyte.edu.tr (A. Yemenicioğlu).
}

[2-4]. This reaction initiated by PPO is called enzymatic browning and it causes loss of quality during processing of fruits and vegetables, mushrooms and some crustacean species $[2,5,6]$. Thus, different methods such as chemical inhibition or heat inactivation of PPO has been developed to prevent this reaction during food processing [2,7]. In mushrooms (Agaricus bisporus), possibly one of the most susceptible products to enzymatic browning, the major PPO form is tyrosinase [8]. It was reported that the fungal tyrosinases have some important roles in the formation and stability of spores, in defense and virulence mechanisms, and in browning and pigmentation of fungi [9]. It was also proposed that the cresolase activity of tyrosinase has some important roles in the formation of antioxidants having genoprotective effect in mushrooms [10]. Unlike to plant PPO that is located in lumen of the chloroplast thylakoid, the fungal PPO is presumed to be cytoplasmic [11]. The studies related to A. bisporus tyrosinase suggested that the enzyme is synthesized mainly in the latent form $(67 \mathrm{kDa})$, 
which is gradually transformed into the active form (43 kDa) by endogenous proteases [12]. The data of Wichers et al. [13] who showed that $A$. bisporus tyrosinases' (AbPPO1 and AbPPO2) cDNAs encode proteins of approximately $64 \mathrm{kDa}$ and their translation products are recognized by antibodies directed against a $43 \mathrm{kDa}$ tyrosinase also supported the transformation model of latent tyrosinases to lower molecular weight active forms by some specific proteases following synthesis.

Although, the activity of PPO is undesirable during processing of different foods, there are many technological processes based on reaction of this enzyme. In fact, for many years, the use of PPO in industry, cosmetics, clinical and analytical applications has received much attention from the researchers. Mushrooms are widely used as a potent PPO source as they are readily obtained in relatively large quantities and are inexpensive [3]. In food industry, the use of mushroom PPO was found to be valuable for removal of the astringent and bitter taste of cocoa beans [14] and enzymatic cross-linking of proteins as an alternative to the already established use of transglutaminase [15]. The enzyme shows sufficient monophenolase activity essential for its technological applications in such cases as biosynthesis of $o$-diphenolic antioxidant hydroxytyrosol in an environmentally friendly manner [16] and food colorants such as red-violet betalains and gold colored aurons [17]. Out of food industry, mushroom PPO can be used to remove undesirable phenols, amines and xenobiotics from wastewaters and soil [18,19] and produce biosensors for the detection and quantification of phenolic compounds [20-22]. Several clinical applications such as using PPO as a catalyst to produce L-DOPA, a drug for the treatment of Parkinson's disease [23], marker of vitiligo and tumor suppressing and prodrug therapy agent [3] also attract considerable interest. Thus, to stabilize the enzyme and increase its reusability in different industrial processes, the mushroom PPO has been immobilized onto different supports including PALL Biodyne, nylon, polyethersulfone, $\gamma$-alumina, carbon paste, alginate, gelatin, etc. [24-26].

Although their kinetic properties are quite suitable for many different industrial, clinical and research purposes, significant variations in activity, isoenzyme composition and purity of different lots of commercial mushroom PPO preparations [27] cause some major problems in effective use of this enzyme. The heterogeneity of commercial mushroom PPOs is due mainly to differences in PPO activity and isoenzyme composition at different mushroom tissues (stem, cap flesh, cap skin, gill) in different development stages [28-31]. Therefore, by production of this industrially important enzyme from a specific mushroom tissue and by careful monitoring of maturity stage and sizing of mushrooms it can be possible to reduce the heterogeneity of PPO preparations. The use of mushroom stem in PPO production might be very beneficial, since this material is a waste obtained during processing of mushrooms. In the literature, there are several reports related to activity and isoenzyme patterns [28-30,32] of mushroom stem PPO. However, data related specifically to the purification of mushroom stem PPO and kinetic characterization of its monophenolase activity scarce. Thus, the present study aims the partial purification of PPO from mushroom stem by different methods and kinetic characterization of its technologically critical monophenolase activity. The studies were conducted for different parties of mushroom stems to determine the potential variations of PPO activity and characteristics depending on material. The storage stability of mushroom stem PPO lyophilized in presence of different supporting materials was also studied to evaluate the suitability of enzyme as a source of different applications.

\section{Materials and methods}

\subsection{Materials}

Mushrooms (A. bisporus) of the same local packaging company were periodically obtained from a supermarket in Izmir (Turkey). The samples brought to laboratory were washed and their stems were cut and processed to acetone powder (AP). The dialysis tubes (cut-off: 12,000 MW), dextran (MW is 73.200), sodium salt of alginic acid (viscosity of $2 \%$ solution at $25{ }^{\circ} \mathrm{C}$ is $3500 \mathrm{cpc}$ ), insoluble polyvinylpolypyrrolidone (PVPP) were obtained from Sigma Chem. Co. (St. Louis, MO, USA).

\subsection{Enzyme extraction}

All PPO extractions were conducted by using acetone powder (AP) obtained by slightly modifying the method described by Yemenicioglu et al. [33]. During preparation of APs the mushrooms were homogenized with two-fold of acetone for three times by using insoluble PVPP (\%2 of sample weight) only in the first homogenization. The enzyme extraction was performed by suspending $4 \%$ or $6 \%(\mathrm{w} / \mathrm{v}) \mathrm{AP}$ and insoluble PVPP in $0.05 \mathrm{M}$ Na-phosphate buffer ( $\mathrm{pH} 7.0)$. After stirring at $4{ }^{\circ} \mathrm{C}$ for $30 \mathrm{~min}$ with a magnetic stirrer, the extract was filtered through four layers of cheese-cloth and clarified by centrifugation at $10,000 \times g$ and $4{ }^{\circ} \mathrm{C}$ for $15 \mathrm{~min}$.

\subsection{Partial purification}

Crude PPO extracts prepared from APs were partially purified by two different precipitation methods. For ammonium sulfate precipitation, solid ammonium sulfate was slowly added to enzyme extract up to $90 \%$ saturation. The mixture was stirred slowly for $2 \mathrm{~h}$ at $4{ }^{\circ} \mathrm{C}$ and the precipitate was collected by centrifugation at $15,000 \times g$ and $4{ }^{\circ} \mathrm{C}$ for $45 \mathrm{~min}$. The resulting precipitate was then dissolved in $0.05 \mathrm{M} \mathrm{Na-phosphate} \mathrm{buffer} \mathrm{(pH} \mathrm{7.0)} \mathrm{and} \mathrm{dialyzed} \mathrm{for}$ $24 \mathrm{~h}$ at $4{ }^{\circ} \mathrm{C}$ against distilled water $(3 \times 2000 \mathrm{~mL})$. For acetone precipitation, two volumes of cold acetone at $-18{ }^{\circ} \mathrm{C}$ were added to one volume of crude enzyme extract as described by Dijkstra and Walker [34]. After $10 \mathrm{~min}$ stirring at $4{ }^{\circ} \mathrm{C}$, the precipitate formed was collected by centrifugation at $15,000 \times g$ and $0{ }^{\circ} \mathrm{C}$ for $15 \mathrm{~min}$ and dissolved in $0.05 \mathrm{M} \mathrm{Na}$-phosphate buffer ( $\mathrm{pH}$ 7.0). The enzyme was then dialyzed for $24 \mathrm{~h}$ at $4{ }^{\circ} \mathrm{C}$ against distilled water $(3 \times 2000 \mathrm{~mL})$. In partial purification studies average of two or three measurements was used in activity determination.

\subsection{Activity determination}

Enzyme activities were determined at $30^{\circ} \mathrm{C}$ by using a Shimadzu (Model 2450) spectrophotometer equipped with a constant temperature cell holder. All activity measurements were conducted with a quartz cuvette by forming $3 \mathrm{~mL}$ reaction mixtures. The monophenolase activity of PPO was determined by using L-tyrosine (at $0.67 \mathrm{mM}$ ) or phloridzin (at $0.73 \mathrm{mM}$ ) as substrates and $0.05 \mathrm{M}$ Na-phosphate ( $\mathrm{pH} 7.0$ ) or $0.05 \mathrm{M} \mathrm{Na-acetate}(\mathrm{pH}$ 5.0) as buffer, respectively. The increases in absorbance were recorded at 280 and $420 \mathrm{~nm}$ for L-tyrosine and phloridzin for 20-30 min, respectively. Enzyme activity was determined from the linear portion of absorbance versus time curve following the initial lag period (10-15 min). The diphenolase activity of PPO was determined by using L-DOPA (at $0.33 \mathrm{mM}$ ) or catechol (at $1.67 \mathrm{mM}$ ) as substrate and $0.05 \mathrm{M} \mathrm{Na}$ phosphate as buffer ( $\mathrm{pH}$ 7.0). The increase in absorbance was determined at 475 
and $420 \mathrm{~nm}$ for L-DOPA and catechol for 1-2 min, respectively. Enzyme activity was calculated from the slope of the initial linear portion of absorbance vs. time curve. Activities of enzymes were expressed as percent initial activity or Unit (0.001 absorbance change in $1 \mathrm{~min})$.

\subsection{Characterization studies}

Characterization studies were based on monophenolase activity assayed by L-tyrosine (at $0.67 \mathrm{mM}$ ) and PPO was partially purified by using ammonium sulfate precipitation unless otherwise indicated in the text. Thermal stability of monophenolase activity was determined by $30 \mathrm{~min}$ incubation of $0.6 \mathrm{~mL}$ aliquots of extracts in TIT (Thermal Inactivation Time) tubes (i.d. $9 \mathrm{~mm}$; wall thickness, $1 \mathrm{~mm}$ ) between 35 and $60{ }^{\circ} \mathrm{C}$. Effect of temperature on monophenolase activity was determined by assaying activity between 25 and $40{ }^{\circ} \mathrm{C}$. Effect of $\mathrm{pH}$ on monophenolase activity was determined by assaying monophenolase activity against L-tyrosine $(0.53 \mathrm{mM})$ in different buffers $(0.1 \mathrm{M}$ acetate (at $\mathrm{pH} 4.0$ or 5.0), Na-phosphate (at pH 6.0, 6.6 or 7.0) or Tris- $\mathrm{HCl}$ (at $\mathrm{pH}$ 8.0) buffers). The $\mathrm{pH}$ stabilities were determined by mixing suitable amounts of enzyme extract and $0.1 \mathrm{M}$ appropriate buffer (given in optimum $\mathrm{pH}$ determination) at $\mathrm{pH} 4.0,5.0,6.0,6.6,7.0$ or 8.0. The enzyme-buffer mixtures were incubated at $4{ }^{\circ} \mathrm{C}$ for $24 \mathrm{~h}$ and their remaining monophenolase activities were determined at $\mathrm{pH} 7.0$ by using L-tyrosine as substrate and $0.5 \mathrm{M}$ Na-phosphate as buffer ( $\mathrm{pH}$ 7.0). The kinetic parameters, $K_{\mathrm{m}}$ and $V_{\max }$, were determined by measuring enzyme activity at different concentrations of L-tyrosine $(0.67-0.067 \mathrm{mM})$ and plotting data to a double reciprocal plot. The substrate specificity of the PPO was determined by measuring its activity against L-DOPA, L-tyrosine, pyrogallol, catechol, 4-methyl catechol, (+) catechin, hydroquinone and phloroglucinol. The activities of enzyme in substrate specificity tests were determined by using one of the indicated substrates (at $0.26 \mathrm{mM}$ ) and $0.05 \mathrm{M}$ Na-phosphate buffer (pH 7.0). In characterization studies, the average of two or three activity measurements was used for calculation of enzyme activity.

\subsection{Storage stability of different lyophilized forms}

Lyophilized enzymes were prepared by dissolving different amounts of dextran $(2 \%)$, sucrose $(4 \%)$ or alginate $(1 \%)$ in ammonium sulfate precipitated and dialyzed enzyme extracts as supporting materials. The extracts were then lyophilized by using a freeze drier (Labconco, FreeZone, 6 liter, Kansas City, MO, USA). The stability of monophenolase and diphenolase activity of PPO in different lyophilized forms was investigated for 6 or 6.5 months storage period at $-18{ }^{\circ} \mathrm{C}$. For activity determinations, lyophilized enzymes were dissolved in $0.05 \mathrm{M}$ Na-phosphate buffer ( $\mathrm{pH}$ 7.0) and assayed for monophenolase or diphenolase activities by using L-tyrosine or L-DOPA as described in activity determination above, respectively. The average of three measurements was used in activity calculations.

\subsection{Protein content}

Protein was determined by the Lowry method using bovine serum albumin as standard [35].

\section{Results and discussion}

\subsection{Distribution of PPO activity in mushroom tissues}

Crude extracts obtained from mushroom stem APs contained almost 3-4.5- and 2-3.5-fold lower monophenolase and diphenolase activities than those from mushroom cap, respectively (Table 1). However, differences for the specific activities of different tissues were not more than two-fold due to the higher protein content in AP extracts of mushroom caps. The ratio of dipenolase (L-DOPA) to monophenolase (Ltyrosine) activity in specific mushroom tissues indicated that in
Table 1

Distribution of PPO and monophenolase (L-tyrosine) to diphenolase (L-DOPA) activity ratios in different mushroom sections

\begin{tabular}{|c|c|c|c|c|c|c|}
\hline \multirow[t]{2}{*}{$\mathrm{AP} \neq$} & \multicolumn{2}{|c|}{ Monophenolase } & \multicolumn{2}{|c|}{ Diphenolase } & \multicolumn{2}{|l|}{ Ratio } \\
\hline & Stem & Cap & Stem & Cap & Stem & Cap \\
\hline \multicolumn{7}{|l|}{ AP-1 } \\
\hline Activity (U/g AP) & 520 & 1499 & 2929 & 4,988 & 5.6 & 3.3 \\
\hline Specific activity (U/mg) & 82 & 119 & 464 & 395 & & \\
\hline \multicolumn{7}{|l|}{ AP-2 } \\
\hline Activity (U/g AP) & 1015 & 4704 & 5401 & 19,311 & 5.3 & 4.1 \\
\hline Specific activity (U/mg) & 137 & 288 & 727 & 1,184 & & \\
\hline
\end{tabular}

the caps, the monophenolase activity occupies a greater portion of PPO activity. This result suggested the different nature of mushroom stem PPO than the mushroom cap PPO is in line with that of Moore and Flurkey [28], who determined 3-5.5fold lower monophenolase activity in mushroom stem than in mushroom cap flesh and cap skin. However, these researchers did not report significant differences among diphenolase activities of mushroom stem, cap flesh and cap skin. The results of this study, on the other hand, contradict with those of Zhang and Flurkey [32] who determined the PPO diphenolase activity in portobella mushroom (a brown strain of $A$. bisporus) stems 1.5- and 2.5-fold higher than in cap skin and flesh, respectively.

\subsection{PPO activity in mushroom stem APs}

The activity measurements in different APs (AP-1 to AP-8) showed the considerable variation in monophenolase and diphenolase activities of PPO in different parties of mushroom stems (Tables 1-3). Monophenolase and diphenolase activities of APs, based on crude extract measurements for L-tyrosine and L-DOPA, changed between 440 and 2455 U/g AP (average: $1011 \pm 626$ ) and 2178 and $10,821 \mathrm{U} / \mathrm{g}$ AP (average: $5163 \pm 3059)$, respectively. However, the ratio of diphenolase (L-DOPA) to monophenolase (L-tyrosine) activity in crude extracts did not vary significantly (average: $5.4 \pm 0.7$ ). Thus, it seems that the balance between monophenolase and diphenolase activities of PPO was maintained in different parties of mushroom stems. However, the ratio of diphenolase to monophenolase activity determined in this study is significantly different from that same ratio of 31.4 reported by Moore and Flurkey [28] for mushroom stem PPO assayed against the same substrates. This significant difference in diphenolase to monophenolase activity ratios for mushroom stem PPOs may be due to the different extraction methods used by these workers, or differences in strains of mushrooms or environmental conditions during development of mushrooms.

\subsection{Effect of partial purification on PPO activity}

The average specific monophenolase and diphenolase activities of PPOs (AP-3 to AP-8) in crude and ammonium sulfate precipitated extracts were $153 \pm 43$ and $785 \pm 196 \mathrm{U} /$ $\mathrm{mg}$, and $475 \pm 98$ and $2290 \pm 617 \mathrm{U} / \mathrm{mg}$ for L-tyrosine and 
Table 2

Specific activities and diphenolase (L-DOPA) to monophenolase (L-tyrosine) activity ratios in crude and ammonium sulfate precipitated mushroom stem PPO extracts

\begin{tabular}{|c|c|c|c|c|c|c|}
\hline \multirow[t]{2}{*}{$\mathrm{AP} \neq$} & \multirow[t]{2}{*}{ Substrate } & \multirow{2}{*}{$\begin{array}{l}\text { Activity } \\
(\mathrm{U} / \mathrm{g} \text { AP })^{\mathrm{a}}\end{array}$} & \multicolumn{2}{|c|}{ Specific activity (U/mg) } & \multicolumn{2}{|c|}{ Ratio } \\
\hline & & & $\mathrm{CE}^{\mathrm{b}}$ & $P P E^{c}$ & $\mathrm{CE}$ & PPE \\
\hline \multirow[t]{2}{*}{ AP-3.1 } & L-tyrosine & 1,245 & 201 & 611 & - & - \\
\hline & Catechol & 91,168 & 14,699 & 50,666 & & \\
\hline \multirow[t]{2}{*}{ AP-3.2 } & L-tyrosine & 867 & 145 & 383 & 6.8 & 8.6 \\
\hline & L-DOPA & 5,874 & 979 & 3,299 & & \\
\hline \multirow[t]{2}{*}{ AP-4. 1} & L-tyrosine & 538 & 98 & 416 & 6.0 & 3.9 \\
\hline & L-DOPA & 3,255 & 592 & 1,633 & & \\
\hline \multirow[t]{2}{*}{ AP- 4.2} & L-tyrosine & 455 & 108 & 419 & 5.8 & 5.1 \\
\hline & L-DOPA & 2,625 & 623 & 2,118 & & \\
\hline \multirow[t]{2}{*}{ AP-5 } & L-tyrosine & 916 & 142 & 525 & 4.8 & 4.4 \\
\hline & L-DOPA & 4,415 & 685 & 2,299 & & \\
\hline \multirow[t]{3}{*}{ AP-6 } & L-tyrosine & 1,758 & 170 & 482 & 5.9 & 4.8 \\
\hline & L-DOPA & 10,464 & 1,010 & 2,313 & & \\
\hline & Phloridzin & 782 & 75 & 294 & & \\
\hline \multirow[t]{2}{*}{$\mathrm{AP}-7^{\mathrm{d}}$} & L-tyrosine & 2,455 & 223 & 607 & 4.4 & 4.6 \\
\hline & L-DOPA & 10,821 & 985 & 2,811 & & \\
\hline \multirow[t]{4}{*}{ AP- $8^{d}$} & L-tyrosine & 1,448 & 142 & 357 & 4.4 & 4.4 \\
\hline & L-DOPA & 6,319 & 618 & 1,559 & & \\
\hline & Phloridzin & 626 & 61 & 87 & & \\
\hline & Catechol & 165,292 & 16,175 & 29,936 & & \\
\hline
\end{tabular}

${ }^{a}$ Calculations were based on crude extract measurements.

b CE: Crude extract.

c PPE: Partially purified extract.

${ }^{d}$ In these APs, the standard extraction mixture was changed to $4 \%(\mathrm{w} / \mathrm{v})$ acetone powder and 4\% (w/v) insoluble PVPP in Na-phosphate buffer as described in Section 2.

L-DOPA, respectively. The purification folds achieved for these substrates changed between 2 and 4 for monophenolase and diphenolase activities. On the other hand, the increase in specific monophenolase and diphenolase activities in two different ammonium sulfate precipitations were 1.4- and 3.9-fold for monophenolase activity against phloridzin and 1.9- and 3.4-fold for diphenolase against catechol, respectively (Table 2). The use of phloridzin by mushroom stem PPO is particularly important as this substrate is used for enzymatic biosynthesis of antioxidant compounds and food colorants [36]. Except for several AP extracts, partial purification with ammonium sulfate precipita-

Table 3

Specific activities and diphenolase (L-DOPA) to monophenolase (L-tyrosine) activity ratios in crude and acetone precipitated mushroom stem PPO extracts

\begin{tabular}{|c|c|c|c|c|c|c|}
\hline \multirow[t]{2}{*}{$\mathrm{AP} \neq$} & \multirow[t]{2}{*}{ Substrate } & \multirow{2}{*}{$\begin{array}{l}\text { Activity } \\
(\mathrm{U} / \mathrm{g} \text { AP) }\end{array}$} & \multicolumn{2}{|c|}{ Specific activity (U/mg) } & \multicolumn{2}{|c|}{ Ratio } \\
\hline & & & $\overline{\mathrm{CE}^{\mathrm{b}}}$ & $\overline{\mathrm{PPE}^{\mathrm{c}}}$ & $\mathrm{CE}$ & PPE \\
\hline AP-4.3 & $\begin{array}{l}\text { L-tyrosine } \\
\text { L-DOPA }\end{array}$ & $\begin{array}{r}440 \\
2178\end{array}$ & $\begin{array}{r}82 \\
404\end{array}$ & $\begin{array}{r}561 \\
1507\end{array}$ & 4.9 & 2.7 \\
\hline AP- 4.4 & $\begin{array}{l}\text { L-tyrosine } \\
\text { L-DOPA }\end{array}$ & $\begin{array}{r}476 \\
2508\end{array}$ & $\begin{array}{r}87 \\
460\end{array}$ & $\begin{array}{r}497 \\
1601\end{array}$ & 5.3 & 3.2 \\
\hline
\end{tabular}

\footnotetext{
${ }^{a}$ Calculations were based on crude extract measurements.

${ }^{\mathrm{b}} \mathrm{CE}$ : Crude extract.

${ }^{c}$ PPE: Partially purified extract.
}

tion caused also a slight or moderate drop in the ratio of diphenolase to monophenolase activities.

The effects of two-fold acetone precipitation and $90 \%$ ammonium sulfate precipitation on specific diphenolase and monophenolase activities were also compared in AP-4 extracts (Tables 2 and 3). The application of acetone precipitation increased the average specific monophenolase activity against L-tyrosine almost $20 \%$. However, it also caused almost a $20 \%$ decline in the average specific diphenolase activity against L-DOPA (Table 3). The change of specific activities reduced the ratio of diphenolase to monophenolase activities significantly. Thus, it appears that the acetone precipitation may be a more suitable method when a lower diphenolase to monophenolase activity ratio is desired in a specific industrial or clinical application.

\subsection{Thermal stability}

As seen in Fig. 1, the enzyme did not show a considerable inactivation up to $45^{\circ} \mathrm{C}$. The considerable inactivation of PPO started above $45^{\circ} \mathrm{C}$ and accelerated by further increase of the heating temperature. However, the enzyme maintained 23-36\% of its activity after $30 \mathrm{~min}$ at $60{ }^{\circ} \mathrm{C}$. There were no considerable differences in thermal stabilities of ammonium sulfate precipitated enzymes obtained from AP-3 and AP-4. Partial purification with ammonium sulfate or acetone precipitation did not also affect the thermal stability of enzymes obtained from AP-4. Ikehata and Nicell [18] found that the monophenolase activity of commercial mushroom PPO is heat labile and lost $90 \%$ of its initial activity at $50{ }^{\circ} \mathrm{C}$ after $38 \mathrm{~min}$ incubation (at pH 7.0). In contrast, Arıca et al. [37] reported that the commercial mushroom PPO maintained almost $95 \%$ and $70 \%$ of its monophenolase activity after $30 \mathrm{~min}$ heating at 50 and $60{ }^{\circ} \mathrm{C}$, respectively (at $\mathrm{pH} 6.5$ ). These reports showing the diversity of the thermal stability of mushroom PPO suggest a moderate heat stability for monophenolase activity of mushroom stem PPO.

\subsection{Effect of temperature}

Effect of temperature on monophenolase activity of PPO was studied between 25 and $40{ }^{\circ} \mathrm{C}$, a temperature range at

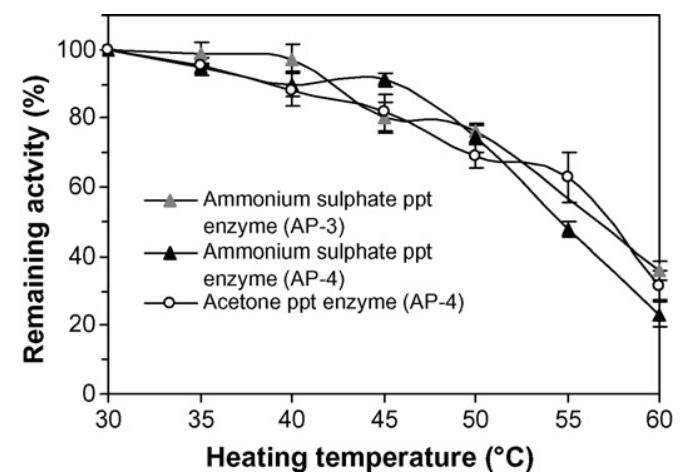

Fig. 1. Thermal stability of monophenolase activity of mushroom stem PPO (heating period was $30 \mathrm{~min}$ ). 
which almost no enzyme inactivation was observed during thermal stability tests. As seen in Fig. 2, the activities of enzymes from different APs effected similarly from temperature change and showed maximal activity at $40{ }^{\circ} \mathrm{C}$. The temperature-monophenolase activity profile of enzymes observed in this study differs from those of partially purified mushroom PPO [23,26] and commercial mushroom PPO [37], which gave sharp peaks at 20 and $30{ }^{\circ} \mathrm{C}$, respectively. In the temperature range studied, the activation energies $\left(E_{\mathrm{a}}\right)$ calculated from Arrhenius plot were 31.4 and $29.4 \mathrm{~kJ} / \mathrm{mol}$ for the monophenolase activity of PPO from AP-3 and AP-8, respectively. These $E_{\text {a }}$ values showed the quite similar temperature dependencies of PPO in different mushroom stem APs. However, the $E_{\mathrm{a}}$ values calculated in this study are almost 6.4-6.8-fold lower than the $E_{\mathrm{a}}$ value of $200 \mathrm{~kJ} / \mathrm{mol}$ reported by Sharma et al. [23] for the monophenolase activity of partially purified mushroom PPO. Thus, it is clear that significantly greater temperature changes are needed to affect the monophenolase activity of mushroom stem PPO. This may be an advantage during the industrial applications where a certain amount of enzyme activity is desired under variable process temperatures.

\subsection{Effect of $p H$}

Monophenolase activity of mushroom stem PPO has a broad $\mathrm{pH}$ optimum with estimated values between $\mathrm{pH} 6.0$ and 8.0, but there was practically no activity below $\mathrm{pH} 5.0$ (Fig. 3). The PPO purified by acetone precipitation showed slightly lower activity at $\mathrm{pH} 8.0$ than the PPOs purified with ammonium sulfate precipitation. On the other hand, there is no difference between the $\mathrm{pH}$ profiles of PPOs partially purified by ammonium sulfate from $\mathrm{AP}-3$ and $\mathrm{AP}-4$. The $\mathrm{pH}$ profiles obtained in this study between $\mathrm{pH} 6.0$ and 8.0 for monophenolase activity are similar with that profile reported by Ikehata and Nicell [18] for the monophenolase activity of commercial mushroom PPO. However, the commercial enzyme used by these workers was more active at $\mathrm{pH}$ 5.0. Arica et al. [37] also reported that at $\mathrm{pH} 4.0$, the commercial mushroom PPO showed $30 \%$ of its monophenolase activity observed at optimum $\mathrm{pH}$. Thus, it seems that the commercial mushroom PPO is more active in the acidic region than the mushroom stem PPO.

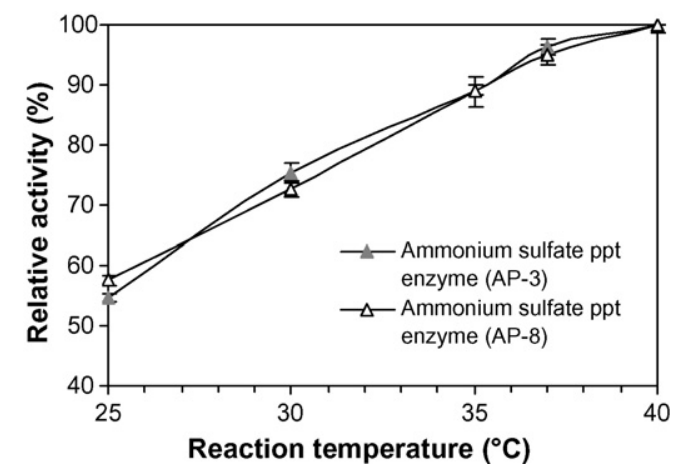

Fig. 2. Effect of temperature on monophenolase activity of mushroom stem PPO.

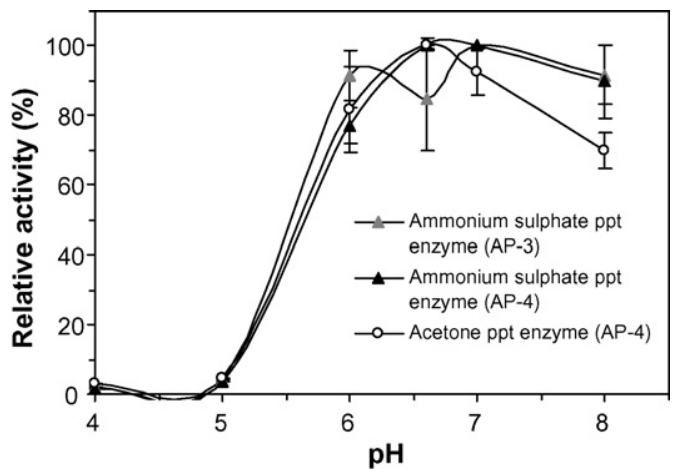

Fig. 3. Effect of $\mathrm{pH}$ on monophenolase activity of mushroom stem PPO.

\section{7. $p H$ stability}

PPOs obtained from different parties of mushroom stems by ammonium sulfate or acetone precipitation showed maximum stability at $\mathrm{pH} 7.0$ and 8.0 (Fig. 4). In 5.0-6.5 pH range, the enzymes extracted from AP-4 and partially purified by different methods showed also good stability by maintaining more than $60 \%$ of their initial monophenolase activity. However, in the same $\mathrm{pH}$ range, the enzyme extracted from AP-3 lost most of its activity at $\mathrm{pH}$ 6.0. The enzymes partially purified from AP-3 or AP-4 showed instability also at $\mathrm{pH}$ 4.0. However, all PPOs showed a good stability when incubation $\mathrm{pH}$ was increased slightly to 5.0. The complete or significant loss in monophenolase activity of tyrosinases by slight $\mathrm{pH}$ changes is a phenomenon that can be observed at different $\mathrm{pH}$ values. For example, for commercial mushroom PPO, the loss of monophenolase activity was observed at $\mathrm{pH} 3.0,4.0$ and 5.0, while the enzyme is very stable at $\mathrm{pH} 6.0$ [18]. The same phenomenon was observed at $\mathrm{pH} 3.0$ for the monophenolase activity of a wild edible mushroom (Macrolepiota mastoidea), while the enzyme showed highest stability at $\mathrm{pH} 4.0$ [38]. The loss of labile monophenolase activity was also frequently observed during purification of PPO by different workers $[2,39,40]$. The $\mathrm{pH}$ effect on loss of monophenolase activity may be related to structural changes in enzyme. In fact, it was reported that the monophenolase activity is highly connected with the associated PPO subunits [2]. Thus, it is possible that the dissociation of the subunits of this enzyme or conformational changes in its optimal configuration may be triggered at specific $\mathrm{pH}$ values. The $\mathrm{pH}$ might also affect the amount of different tyrosinase forms (met-tyrosinase, oxy-tyrosinase and deoxy-tyrosinase) of native enzyme during incubation. It was reported that the presence of at least small amount of oxytyrosinase in the native enzyme is essential to produce sufficient amount of diphenol and establish the active monophenolase cycle [41]. The met-tyrosinase form lacks monophenolase activity since binding of monophenol to this form scavenges part of tyrosinase from the catalytic turnover as a dead-end complex in the steady state of monophenolase activity [41-44]. The change of the $\mathrm{pH}$ stability for oxy-tyrosinase in different mushroom PPOs may be related with differences in the environmental conditions during development of mushrooms and/or differences in maturity stage of mushrooms that may be 


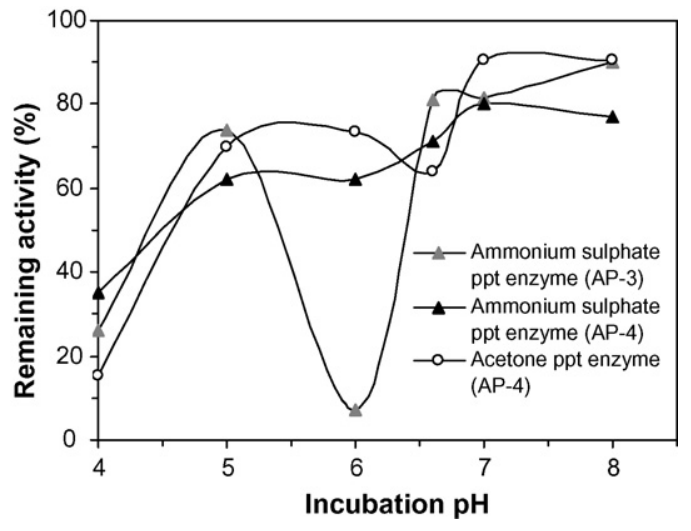

Fig. 4. $\mathrm{pH}$ stability of monophenolase activity of mushroom stem PPO (incubation period was $24 \mathrm{~h}$ at $4{ }^{\circ} \mathrm{C}$ ).

very effective on activity and molecular properties of PPO enzyme [30,31].

\subsection{Kinetic properties}

The $K_{\mathrm{M}}$ and $V_{\max }$ values of monophenolase activity of ammonium sulfate precipitated PPO extracted from AP-3 and AP-6 were $0.39 \mathrm{mM}$ and $0.052 \Delta \mathrm{abs} / \mathrm{min} / \mathrm{mL}$ and $0.34 \mathrm{mM}$ and $0.25 \Delta \mathrm{abs} / \mathrm{min} / \mathrm{mL}$ for L-tyrosine, respectively (Fig. 5). The calculated $K_{\mathrm{m}}$ values of PPOs from APs do not differ significantly from each other, but they are higher than the $K_{\mathrm{m}}$ values of $0.21 \mathrm{mM}$ [45] and $0.25 \mathrm{mM}$ [46] for whole mushroom PPO, and lower than the $K_{\mathrm{m}}$ of $0.58 \mathrm{mM}$ [37] for commercial mushroom PPO.

\subsection{Substrate specificity}

PPOs extracted from AP-6 and AP-8 were most active with o-diphenols including catechol, (+) catechin and 4-methylcatechol and a triphenol, pyrogallol (Table 4). However, relatively lower activities were determined for o-diphenol, L-DOPA. The PPO extracted from AP-6 showed greatest activity against catechol, whereas PPO extracted from AP-8 oxidized mainly 4-methylcatechol. However, there are no significant differences in specificities of PPOs against other substrates. As expected, the action of enzymes' monophenolase activity on L-tyrosine is slow. The enzymes did not also show activity against

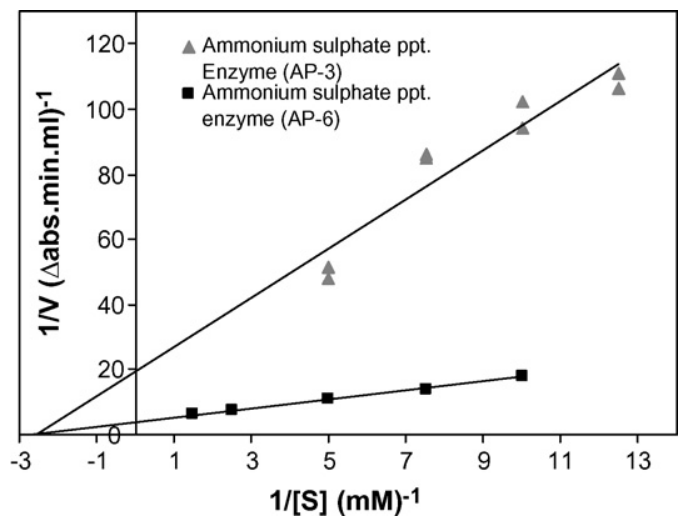

Fig. 5. Double reciprocal plots of monophenolase activity of mushroom stem PPO.

Table 4

Substrate specificity of ammonium sulfate precipitated PPO from mushroom stems

\begin{tabular}{llcr}
\hline Substrate & Wavelength $(\mathrm{nm})^{\mathrm{a}}$ & \multicolumn{2}{c}{$\%$ Activity relative to highest activity } \\
\cline { 3 - 4 } & & AP-6 & AP-8 \\
\hline Catechol & 420 & 100 & 71 \\
$(+)$ Catechin & 420 & 89 & 82 \\
4-methylcatechol & 400 & 75 & 100 \\
Pyrogallol & 440 & 31 & 32 \\
L-DOPA & 475 & 13 & 12 \\
L-tyrosine & 280 & 2 & 2 \\
Phloroglucinol & 210 & 0 & 0 \\
Hydroquinone & 420 & 0 & 0
\end{tabular}

a The wavelength of spectrophotometric measurement.

${ }^{\mathrm{b}}$ In this AP, the standard extraction mixture was changed to $4 \%(\mathrm{w} / \mathrm{v})$ acetone powder and $4 \%(\mathrm{w} / \mathrm{v}$ ) insoluble PVPP in Na-phosphate buffer as described in Section 2.

phloroglucinol (a triphenolic substrate) and hydroquinone (a p-diphenolic substrate).

\subsection{Storage stability of different lyophilized forms}

The monophenolase (L-tyrosine) and diphenolase (LDOPA) activity of PPO lyophilized by sucrose showed a very high stability during 6.5 months storage at $-18{ }^{\circ} \mathrm{C}$ (Table 5). In fact, a slight to moderate (up to $32 \%$ ) activation was observed in the diphenolase activity of the enzyme lyophilized by sucrose.

Table 5

Stability of ammonium sulfate precipitated PPO monophenolase (L-tyrosine) and diphenolase (L-DOPA) activities in different lyophilized forms stored at $-18{ }^{\circ} \mathrm{C}$

\begin{tabular}{|c|c|c|c|c|c|c|}
\hline \multirow[t]{3}{*}{ Time (months) } & \multicolumn{6}{|c|}{ Type of supporting material used in lyophilization } \\
\hline & \multicolumn{3}{|c|}{ Monophenolase activity (U/g) } & \multicolumn{3}{|c|}{ Diphenolase activity $(\mathrm{U} / \mathrm{g})$} \\
\hline & Sucrose & Dextran & Alginate & Sucrose & Dextran & Alginate \\
\hline 0 & $1147(100)$ & $1167(100)$ & 7612 (100) & $6700(100)$ & $9533(100)$ & $52,794(100)$ \\
\hline 0.5 & $1240(108)^{\mathrm{a}}$ & $1253(107)$ & - & $6875(103)$ & $6925(73)$ & - \\
\hline 1 & $1140(99)$ & $1060(91)$ & $7605(100)$ & $7450(111)$ & $8167(86)$ & $47,613(90)$ \\
\hline 2 & 1087 (95) & 1047 (90) & 6659 (87) & 7825 (117) & 7867 (83) & 41,860 (79) \\
\hline 3 & $1113(97)$ & $1040(89)$ & $4016(53)$ & 8867 (132) & 8567 (90) & 21,721 (41) \\
\hline 6 & - & - & $6399(84)$ & - & - & $36,617(69)$ \\
\hline 6.5 & $1127(98)$ & 920 (79) & - & 7150 (107) & $6775(71)$ & - \\
\hline
\end{tabular}

\footnotetext{
${ }^{\text {a }}$ Percent of initial activity.
} 
In the literature, sucrose was reported to have a stabilizing effect on the conformation of different proteins and enzymes in their aqueous solutions [47] and lyophilized forms [48]. Liao et al. [48] attributed the stabilizing effect of sucrose on lysozyme enzyme in dried conditions to its ability to make hydrogen bonds with the enzyme. The monophenolase and diphenolase activities of PPO lyophilized with dextran were also highly stable. The maximal activity loss in diphenolase or monophenolase activities of PPO lyophilized with dextran was almost $30 \%$ by 6.5 months storage. The enzyme lyophilized by alginate, on the other hand, was stable for almost 2 months, but the instability of enzyme caused first the loss of 50-60\% of its activities at the 3rd month and then reactivation of $27-31 \%$ of its activities at the 6th month. The instability of commercial mushroom PPO in cross-linked alginate gels was reported by Munjal and Sawhney [26]. However, the reasons of the instability of enzyme interacted with alginate are not clear. This may be related with gradual changes in enzyme hydrophilic/ hydrophobic balance and/or confirmation by associationdissociation reactions formed among enzyme, protein impurities and alginate molecules during storage.

\section{Conclusions}

The limited variation of diphenolase to monophenolase activity ratios of PPO in different crude extracts suggested the homogeneity of this enzyme in mushroom stems. The lower diphenolase to monophenolase activity ratio of mushroom stem PPO than that from mushroom cap PPO suggested the different nature of stem enzyme. The mushroom stem PPO has a low temperature dependency of activity and broad optimum $\mathrm{pH}$ close to neutrality, but it lacks activity in the acidic region. The use of phloridzin by mushroom stem PPO is particularly important as this substrate is used for enzymatic biosynthesis of antioxidant compounds and food colorants. The differences in extraction material or partial purification method did not considerably affect major biochemical properties of mushroom stem PPO. The good storage stabilities of monophenolase and diphenolase activities of partially purified enzyme lyophilized by different supports showed the suitability of using mushroom stem PPO to obtain commercial preparations. Thus, it seems that the mushroom stems obtained as a waste material during mushroom processing can be used as a more homogenous source than whole mushrooms to obtain PPO for industrial, clinical or research purposes.

\section{Acknowledgements}

This work has been funded by the Research Foundation of Izmir Institute of Technology, Turkey (Grant $\neq 2002$ IYTE 12). We appreciate Dr. Ruhiye Yoruk for her kind assistance in improving the writing of this manuscript.

\section{References}

[1] Mayer AM. Polyphenol oxidases in plants and fungi: going places? A review. Phytochemistry 2006;67:2318-31.
[2] Vamos-Vigyazo L. Polyphenol oxidase and peroxidase in fruits and vegetables. Crit Rev Food Sci 1981;15:49-127.

[3] Seo S, Sharma VK, Sharma N. Mushroom tyrosinase: recent prospects. J Agric Food Chem 2003;51:2837-53.

[4] Yoruk R, Marshall MR. Physicochemical properties and function of plant polyphenol oxidase: a review. J Food Biochem 2003;27:361-422.

[5] Simpson BK, Marshall MR, Otwell WS. Phenoloxidase from shrimp (Penaeus setiferus): purification and some properties. J Agric Food Chem 1987;35:918-21.

[6] Opoku-Gyamfua A, Simpson BK, Squires EJ. Comparative studies on the polyphenol oxidase fraction from lobster and tyrosinase. J Agric Food Chem 1992;40:772-5.

[7] Thomas-Barberan FA, Espin JC. Phenolic compounds and related enzymes as determinants of quality in fruits and vegetables. J Sci Food Agric 2001;81:853-76.

[8] Ratcliffe B, Flurkey WH, Kuglin J, Dawley R. Tyrosinase, laccase and peroxidase in mushrooms (Agaricus, Crimni, Oyster, and Shiitake). J Food Sci 1994;59:824-7.

[9] Halaouli S, Asther M, Sigoillot JC, Hamdi M, Lomascolo A. Fungal tyrosinases: new prospects in molecular characteristics, bioengineering and biotechnological applications. J Appl Microbiol 2006;100:219-32.

[10] Shi Y, Benzie IFF, Buswell JA. Role of tyrosinase in the genoprotective effect of the edible mushroom Agaricus bisporus. Life Sci 2002;70:1595608.

[11] Marusek CM, Trobaugh NM, Flurkey WH, Inlow JK. Comparative analysis of polyphenol oxidase from plant and fungal species. J Inorg Biochem 2006;100:108-23.

[12] Espin JC, Wichers HJ. Activation of a latent mushroom (Agaricus bisporus) tyrosinase isoform by sodium dodecyl sulfate (SDS) Kinetic properties of the SDS-activated isoform. J Agric Food Chem 1999;47: 3518-25.

[13] Wichers HJ, Recourt K, Hendriks M, Ebbelaar CEM, Biancone G, Hoeberichts FA, Mooibroek H, Soler-Rivas C. Cloning expression and characterization of two tyrosinase cDNAs from Agaricus bisporus. Appl Microbial Biotechnol 2003;61:336-41.

[14] Selamat MJ, Bakar J, Saari N. Oxidation of polyphenols in unfermented and partly fermented cocoa beans by cocoa polyphenol oxidase and tyrosinase. J Sci Food Agric 2002;82:559-66.

[15] Thalmann CR, Lötzbeyer T. Enzymatic cross-linking of proteins with tyrosinase. Eur Food Res Technol 2002;214:276-81.

[16] Espin JC, Soler-Rivas C, Cantos E, Tomas-Barberan FA, Wichers HJ. Synthesis of the antioxidant hydroxytyrosol using tyrosinase as biocatalyst. J Agric Food Chem 2001;49:1187-93.

[17] Strack D, Schiliemann W. Bifunctional polyphenol oxidases: novel functions in plant pigment biosynthesis. Angew Chem Int Edit 2001;20: $3791-4$.

[18] Ikehata K, Nicell JA. Characterization of tyrosinase for the treatment of aqueous phenols. Bioresour Technol 2000;74:191-9.

[19] Duran N, Esposito E. Potential applications of oxidative enzymes and phenoloxidase-like compounds in wastewater and soil treatment: a review. Appl Catal B-Environ 2000;28:83-99.

[20] Climent PV, Serralheiro MLM, Rebelo MJF. Development of a new amperometric biosensor based on polyphenoloxidase and polyethersulphone membrane. Pure Appl Chem 2001;73:1993-9.

[21] Freire RS, Thongngamdee S, Duran N, Wang J, Kubota LT. Mixed enzyme (laccase/tyrosinase)-based remote electrochemical biosensor for monitoring phenolic compounds. Analyst 2002;127:258-61.

[22] Freire RS, Ferreira MMC, Duran N, Kubota LT. Dual amperometric biosensor device for analysis of binary mixtures of phenols by multivariate calibration using partial least squares. Anal Chim Acta 2003;485:263-9.

[23] Sharma NM, Kumar S, Sawhney SK. A novel method for the immobilization of tyrosinase to enhance stability. Biotechnol Appl Biochem 2003;38:137-41.

[24] Wang J, Liu J, Cepra G. Thermal stabilization of enzymes immobilized within carbon paste electrodes. Anal Chem 1997;69:3124-7.

[25] Duran N, Rosa MA, D'Annibale A, Gianfreda L. Applications of laccases and tyrosinases (polyphenoloxidases) immobilized on different supports: a review. Enzyme Microb Tech 2002;31:907-31. 
[26] Munjal N, Sawhney SK. Stability and properties of mushroom tyrosinase entrapped in alginate, polyacrylamide and gelatin gels. Enzyme Microb Tech 2002;30:613-9.

[27] Kumar M, Flurkey WH. Activity, isoenzymes and purity of mushroom tyrosinase in commercial preparations. Phytochemistry 1991;30:3899902.

[28] Moore BM, Flurkey WH. Tyrosinase activities and isoenzymes in three strains of mushrooms. J Food Sci 1989;54:1377-8.

[29] Flurkey WH. Identification of tyrosinase in mushrooms by isoelectric focusing. J Food Sci 1991;56:93-5.

[30] Van Leeuwen J, Wichers HJ. Trosinase activity and isoform composition in separate tissues during development of Agaricus bisporus fruit bodies. Mycol Res 1999;103:413-8.

[31] Ingebrigtsen J, Kang B, Flurkey WH. Tyrosinase activity and isoenzymes in developing mushrooms. J Food Sci 1989;54:128-31.

[32] Zhang X, Flurkey WH. Phenoloxidases in Portabella mushrooms. J Food Sci 1997;62:97-100.

[33] Yemenicioğlu A, Özkan M, Cemeroğlu B. Heat inactivation kinetics of apple polyphenoloxidase and activation its latent form. J Food Sci 1997;62:508-10.

[34] Dijkstra L, Walker JRL. Enzymatic browning in apricots (Prunus armeniaca). J Sci Food Agric 1991;54:229-34.

[35] Harris DA. Spectrophotometric assays. In: Harris DA, Bashford CL, editors. Spectrophotometry and spectrofluorometry. Oxford: I.R.L. Press; 1987. p. 59.

[36] Ridgway T, Tucker G, Wiseman H. Novel bioconversions for the production of designer antioxidant and colorant flavonoids using polyphenol oxidases. In: Tombs MP, editor. Biotechnology and Genetic Engineering Reviews. Andover: Intercept; 1997. p. 165.

[37] Arıca MY, Bayramoglu G, Bicak N. Characterization of tyrosinase immobilized onto spacer-arm attached glycidyl methacrylate-based reactive microbreads. Process Biochem 2004;39:200717.

[38] Kolcuoğlu Y, Colak A, Sesli E, Yildirim M, Saglam N. Comparative characterization of monophenolase and diphenolase activities from a wild edible mushroom (Macrolepiota mastoidea). Food Chem 2007;101:77885.

[39] Yemenicioğlu A, Cemeroğlu B. Consistency of polyphenol oxidase (PPO) thermostability in ripening apricots (Prunus armeniaca $L$.): evidence for the presence of thermostable PPO forming and destabilizing mechanisms in apricots. J Agric Food Chem 2003;51:2371-9.

[40] Sanchez-Ferrer A, Laveda F, Garcia-Carmona F. Cresolase activity of potato tuber partially purified in a two-phase partition system. J Agric Food Chem 1993;41:1225-8.

[41] Laveda F, Nunez-Delicado E, Garcia-Carmona F, Sanchez-Ferrer. Proteolytic activation of latent Paraguay peach PPO Characterization of monophenolase activity. J Agric Food Chem 2001;1003-8.

[42] Naish-Byfield S, Riley PA. Tyrosinase kinetics: failure of acceleration in oxidation of ring-blocked monohydric phenol substrate. Pigment Cell Res 1998;11:94-7.

[43] Ros-Martinez JR, Rodriguez-Lopez JN, Castellanos RV, Garcia-Canovas F. Determination between two kinetic mechanisms for the monophenolase activity of tyrosinase. Biochem J 1993;294:621-3.

[44] Escribano J, Cabanes J, Chazarra S, Garcia-Carmona. Characterization of monophenolase activity of table beet polyphenol oxidase. Determination of kinetic parameters on the tyramine/dopamine pair. J Agric Food Chem 1997;45:4209-14.

[45] Fenoll LG, Rodriguez-Lopez JN, Garcia-Molina F, Garcia-Canovas F, Tudela J. Michaelis constants of mushroom tyrosinase with respect to oxygen in the presence of monophenols and diphenols. Int J Biochem Cell B 2002;34:332-6.

[46] Rodriguez-Lopez J, Fenoll LG, Tudela J, Devece C, Sanchez-Hernandez $\mathrm{D}$, de los Reyes E, Garcia-Canovas F. Thermal inactivation of mushroom polyphenoloxidase employing $2450 \mathrm{MHz}$ microwave radiation. J Agric Food Chem 1999;47:3028-35.

[47] Arakawa T, Timasheff S. Stabilization of protein structure by sugars. Biochemistry 1982;21:6536-44.

[48] Liao Y, Brown MB, Martin GP. Investigation of the stabilization of freezedried lysozyme and the physical properties of the formulations. Eur J Pharm Biopharm 2004;58:15-24. 